\title{
Justyna Kobus, Kierunki i dynamika zmian w języku mieszkańców wielkopolskich wsi na przełomie wieków $X X i$ XXI, Wydawnictwo Poznańskiego Towarzystwa Przyjaciół Nauk, Poznań 2015, ss. 193
}

Zasłużone (jak mało które) dla nauki polskiej Wydawnictwo Poznańskiego Towarzystwa Przyjaciół Nauk od kilku lat wydaje cieszącą się w środowisku dialektologów wielką renomą serię materiałów konferencyjnych „Gwary Dziś”, pod redakcją naukową organizatora całego cyklu konferencyjnego, Jerzego Sierociuka. Recenzowana tutaj książka rozpoczyna (jako tom pierwszy) natomiast nową serię: „Gwary Dziś - Monografie”, również pod redakcją Jerzego Sierociuka. Warto więc przyjrzeć się książce Justyny Kobus, która stanowi zapowiedź tego, że odtąd Wydawnictwo będzie drukować nie tylko bardzo cenne, choć z natury rzeczy szkicowe, czasem wyłącznie teoretyczno-metodologiczne czy prognostyczne artykuły gwaroznawcze, lecz także monografie, a więc obszerniejsze i całościowe opracowania, prezentujące oprócz teorii i metodologii także obfity i interesujący materiał językowy.

Książka Justyny Kobus ma układ klasycznej monografii dialektologicznejczy może raczej już bardziej socjolingwistycznej niż dialektologicznej. Już we Wprowadzeniu Autorka sygnalizuje najważniejszy dla niej problem w obrębie przedmiotu badań: „Wraz z postępem technologicznym zmieniło się społeczeństwo, a z nim jego kultura. Przykładem takiego procesu jest chociażby ewolucja realiów wiejskich, szczególnie zaś przejście od prostych narzędzi rolniczych, używanych w XIX i na początku XX w. (np. sierpów i kos, płacht do siewu, motyk do kopania ziemniaków i in.) do wieloczynnościowych maszyn rolniczych o wysokim stopniu zmechanizowania (np. kombajnów zbożowych, siewników, kombajnów do zbioru ziemniaków i in.). Zmiany w sferze kultury materialnej pociągają za sobą naturalne przeobrażenia w sposobie nazywania nowych przedmiotów, urządzeń, maszyn, czynności i wykonawców czynności. 
Z jednej strony powoduje to rozmaite przekształcenia w zasobie leksykalnym mieszkańców wsi, z drugiej - skłania ich do refleksji nad własną mową, wywołuje potrzebę utrwalenia języka przodków w jakiejkolwiek formie, np. nagrania rozmów najstarszych mieszkańców czy opracowania słownika gwary rodzimej wsi" [Kobus 2015: 9].

Następujący później rozdział drugi, Dotychczasowe opracowania przedmiotu [Kobus 2015: 11-14], stanowi bardzo zgrabnie ujęty i przejrzysty wykład tzw. stanu badań. Rozdział ten przedstawia samoistną wartość informacyjną, istotną zwłaszcza dla tych, którzy, dalecy od koniunkturalizmu, mimo nie zawsze korzystnego klimatu badawczego, chcieliby iść drogą wytyczoną przez takich badaczy, jak (w odniesieniu do Wielkopolski) przede wszystkim Adam Tomaszewski, Zenon Sobierajski, Monika Gruchmanowa, Zygmunt Zagórski czy Henryk Nowak.

Rozdział trzeci, Założenia metodologiczne [Kobus 2015: 15-25], jest przekonującym uzasadnieniem potrzeby i konieczności przejścia od klasycznej dialektologii (dążącej, co szczególnie usilnie podkreślał Karol Dejna, do zrekonstruowania idealnego modelu gwary, charakteryzującego się pełnym zestawem i maksymalną frekwencją tekstową właściwych dla niej cech) do socjolingwistyki, zmierzającej do uchwycenia rzeczywistego obrazu uzusu gwarowego, uwarunkowanego czynnikami w szerokim tego słowa znaczeniu społecznymi. Konieczność owego przejścia motywują zmiany na wsi. „Zmiany te polegają na znacznej redukcji odsetka mieszkańców wsi zajmujących się rolnictwem [...], pojawieniu się wielu innych grup zawodowych na wsi oraz zaniku tradycyjnych form więzi społecznej i kultury wiejskiej (urbanizacja wsi). W tym sensie tradycyjna wieś - przynajmniej w krajach wysoko rozwiniętych - przestaje już istnieć. Polska wieś pod wieloma względami nie może być porównywana z wsią w krajach Europy Zachodniej czy Północnej, ale niewątpliwie coraz bardziej przybliża się do tego wzoru, co musi oddziaływać na sposób porozumiewania się jej mieszkańców” [Kobus 2015: 15].

Dalej Autorka zasadnie twierdzi, że na skutek oddziaływania tego rodzaju czynników ,język mieszkańców wsi nie jest już tożsamy z gwarą, którą opisywali dialektolodzy w połowie wieku XX. Tradycyjnie rozumiana gwara pozbawiona została wielu charakterystycznych cech, nie może być pojmowana jako uporządkowany system językowy, zbyt daleko posunięte są rozchwiania i odchylenia od przyjętego paradygmatu.

Nacisk na zmianę terminologii (z gwara na język mieszkańców wsi) kładzie Jerzy Sierociuk [...]" [Kobus 2015: 16]. Można dodać, że wtórują mu w tym względzie tacy znakomici specjaliści, jak Bogusław Dunaj, Kazimierz Ożóg czy Halina Kurek. 
Podejście dialektologiczne z socjolingwistycznym łączy w recenzowanej pracy swoista akrybia (nie można oczywiście powiedzieć: „filologiczna”, lecz można: „empiryczno-lingwistyczna”) w charakterystyce informatorów (Autorka uwzględnia takie parametry, jak: ich pochodzenie, datę urodzenia, wykształcenie, rodzaj wykonywanej pracy, szczególne przeżycia, sytuację badawczą w trakcie pozyskiwania materiału - oficjalna, półoficjalna, nieoficjalna - ewentualne oddziaływanie języków obcych na język mieszkańców wsi, oddalenie wsi od większego miasta - zwykle powiatowego - itd.). Warto wreszcie zauważyć, że uproszczony zapis zebranego materiału językowego mimo nieuniknionych niedokładności umożliwia jednak niezłą orientację w specyfice realizacyjnej (także na poziomie fonetycznym) wypowiedzi informatorów.

Za całkowicie zasadny i reprezentatywny można też uznać wybór badanych miejscowości - głównych (Adamów w Konińskiem, Bukówiec Górny w Leszczyńskiem i Dąbrówka Wielkopolska w Babimojskiem) i dodatkowych (Baranówko, Sowinki i Łowęcin w Poznańskiem oraz Grodzisko w Leszczyńskiem). Nie ma tu już miejsca, by przytoczyć wysoce przekonujące uzasadnienia Autorki, dotyczące zarówno wybranych miejscowości, jak i informatorów.

Ostatecznie Autorka tak określa cel swojej monografii: „Celem niniejszej pracy jest opisanie, na przykładach z pola tematycznego PRACA NA ROLI, zróżnicowania leksykalnego mowy ludności reprezentującej różne poddialekty wielkopolskie w czasach nam współczesnych (materiał pozyskiwany był na początku wieku XXI).

Szczególną uwagę poświęcam problemowi świadomości językowej mieszkańców wsi, zróżnicowania temporalnego, relacji nazwa - znaczenie oraz wewnętrznemu zróżnicowaniu leksyki wielkopolskiej. Wybrane zagadnienia opisuję na tle zróżnicowania pokoleniowego [...]" [Kobus 2015: 27].

W zasadniczym materiałowo-analitycznym i interpretacyjnym rozdziale piątym, Kierunki i dynamika zmian $w$ języku mieszkańców wybranych wsi wielkopolskich [Kobus 2015: 41-157] Autorka gruntownie, wyczerpująco i wielostronnie przeanalizowała i opisała zgromadzony materiał językowy, nie szczędząc przytoczeń, a także - co wydatnie podnosi przejrzystość opisu posługując się tabelami i wykresami. Za szczególnie interesujące i wartościowe uznałbym uwagi o świadomości językowej użytkowników języka wsi, m.in. odnoszące się do genezy (rodzimego - obcego, w praktyce [w Wielkopolsce] niemieckiego pochodzenia), zasięgu regionalnego, wartości stylistycznej, statusu normatywnego, frekwencji tekstowej, rozwarstwienia chronologicznego itd. zebranego słownictwa. Dla dialektologa i etnografa interesujące będą oczywiście także partie tego rozdziału traktujące o stopniu zachowania - też w układzie terytorialnym - tradycyjnych nazw realiów wiejskich. Autorka tak zasad- 
nie charakteryzuje język współczesnej wsi: „Język wsi na początku XXI wieku przedstawia mozaikę zróżnicowań i obszar niezwykle chłonny na wpływy polszczyzny ogólnej. Mamy tu do czynienia z ekspansją języka ogólnego na niespotykaną wcześniej skalę, co powoduje wykolejenia nazw desygnatów, które wyszły z użycia, a nawet kompletną nieznajomość zarówno nazwy, jak i desygnatu, zwłaszcza w pokoleniu ludzi młodych" [Kobus 2015: 99].

Za ważną konstatację uznałbym też stwierdzenie: „Uwzględnianie etnografii w badaniach dialektologicznych przynosi wiele korzyści badawczych. Prócz pozyskania obszernej bazy materiałowej z ciekawymi kontekstami kulturowymi, można dostrzec (niezauważalne drogą zwykłych badań lingwistycznych) interesujące procesy językowo-kulturowe" [Kobus 2015: 125]. Autorka dotarła do nich dzięki wnikliwemu wypytywaniu o różne sposoby nazywania i wykonywania rozmaitych prac i przedmiotów oraz dokładną budowę poszczególnych narzędzi.

W krótkim Zakończeniu [Kobus 2015: 159-160] Badaczka zebrała najważniejsze wyniki swojej pracy (o których była już mowa wyżej; dodałbym tu jeszcze konkluzję końcową: „Przywołany materiał pozwala wnioskować zarówno o kierunku ewolucji języka mieszkańców wsi, jak też o tempie tego procesu. W świetle powyższych przykładów rozwarstwienie [...] jest na tyle widoczne, że podejmowanie dalszych badań nad przeobrażeniami i zróżnicowaniem języka mieszkańców współczesnej wsi wydaje się koniecznością i potrzebą chwili" [Kobus 2015: 160]). Całość zamyka Bibliografia [Kobus 2015: 161-174], Aneks (fragment kwestionariusza i pytania uzupełniające) [Kobus 2015: 175-181], Spis wykresów i tabel [Kobus 2015: 183] oraz Indeks alfabetyczny zgromadzonego materiału [Kobus 2015: 185-193].

Książka Justyny Kobus stanowi obiecującą zapowiedź nowej serii Wydawnictwa Poznańskiego Towarzystwa Przyjaciół Nauk: „Gwary Dziś - Monografie”. 

